\title{
Epicardial dissection may solve the problem of saphenous vein graft length
}

\author{
Faruk Cingoz \\ Department of Cardiovascular Surgery, Gulhane Military Medical Academy, Etlik, Ankara, Turkey
}

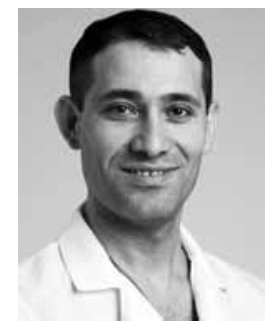

Kardiochirurgia i Torakochirurgia Polska 2015; 12 (1): 60-61

\begin{abstract}
Saphenous vein graft length may be not enough in some cases in aortocoronary bypass surgery. If the graft length is not enough, cardiac surgeons can use epicardial and fatty dissection to release tightening saphenous vein graft, especially in the right coronary artery fashion.
\end{abstract}

Key words: saphenous vein graft, heart surgery.

\section{Introduction}

Accurate adjustment of the length of saphenous vein grafts is one of the most important issues in cardiac surgery. To estimate the exact length of the saphenous vein graft, all cardiac surgeons use some maneuvers such as excessive filling the heart with a pump. Too short saphenous vein graft length might cause tension on the graft. This unwanted situation may lead to compromise in the blood flow in the saphenous vein grafts [1-3]. Herein, we clarify how to deal with this displeasing situation using epicardial and fatty dissection, if the graft length is not enough for proximal anastomosis to the ascending aorta.

\section{Technique}

A saphenous vein graft was anastomosed to the right coronary artery and its proximal site was anastomosed to the ascending aorta. After taking the side clamp, a serious tightening was observed before termination of cardiopulmonary bypass. To change the proximal anastomosis point and to add vein piece to the saphenous vein graft were thought to give the accurate graft length. It was given up because of lack of saphenous vein graft. Epicardial fatty tissue was deeply cut and some venous branches were ligated with titanium clips. The native right coronary artery line was used to place the vein graft. Approximately 2 or $3 \mathrm{~cm}$ graft length was obtained using this technique. The optimal saphenous vein graft length was proved by this dissection (Fig. 1) and overstretching was corrected.

\section{Streszczenie}

W niektórych przypadkach pomostowania aortalno-wieńcowego długość przeszczepianej żyły odpiszczelowej może być niewystarczająca. Jeśli długość przeszczepu jest niewystarczająca, można wykonać dysekcję osierdzia i tkanki tłuszczowej, aby uwolnić uciśnięty przeszczep żyły odpiszczelowej, szczególnie w przypadku pomostowania prawej tętnicy wieńcowej. Słowa kluczowe: przeszczep żyły odpiszczelowej, kardiochirurgia.

\section{Discussion}

To determine the accurate length of saphenous vein grafts may be a problem in cardiac surgery. The heart is decompressed on cardiopulmonary bypass and much smaller than the heart is beating when terminating the pump. If the heart volume increases at the termination of cardiopulmonary bypass or cardiac failure and cardiac distention occurs, a previously acceptable saphenous graft length may become insufficient [1, 2]. If saphenous vein grafts are overstretched because of too short length, ischemia and distention occur, and the grafts may have acute thrombosis [4]. Various techniques have been described for dealing with short graft length $[3,4]$. The most commonly used techniques are to measure lengths with a black silk suture before institution of bypass. It has been reported that it may be useful to measure the distance between the approximate proximal and distal anastomose points to adjust the appropriate saphenous vein graft length via a black silk suture. The other techniques are partially occluding the venous line when filling the graft with blood and measuring the vein grafts up to the chosen points on the aorta. These methods either are not very easily done or are not accurate, and the length adjustment remains a problem for cardiac surgeons.

Epicardial dissection should be borne in mind of cardiac surgeons as an alternative approach and can prove to be useful knowledge when a saphenous vein graft is too short in cardiac surgery. 

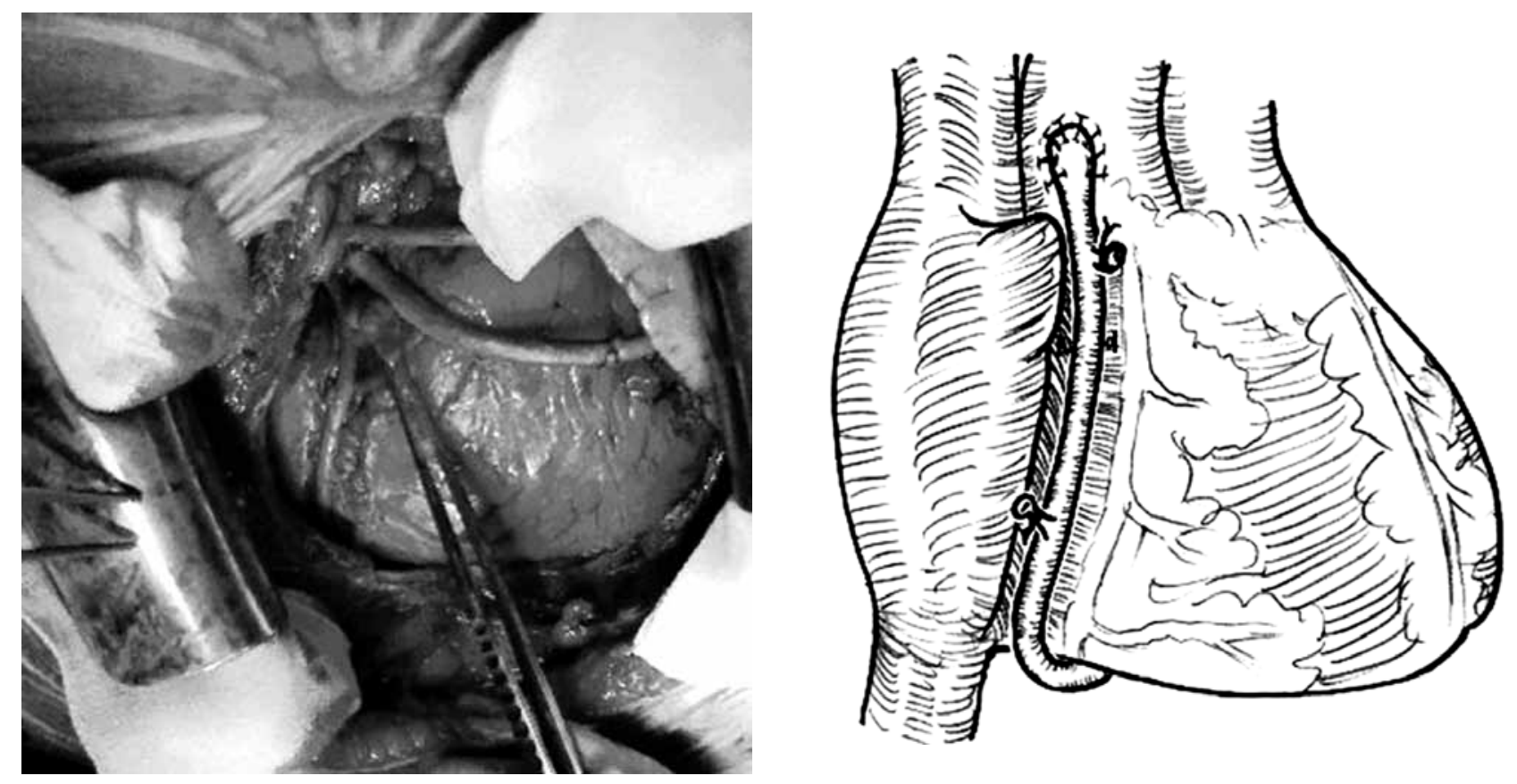

Fig. 1. Dissected right coronary artery line, placed vein graft, and illustration of the placed graft

\section{Disclosure}

Author reports no conflict of interest.

\section{References}

1. Urschel HC, Razzuk MA, Wood RE, Paulson DL. Factors influencing patency of aortocoronary artery saphenous vein grafts. Surgery 1972; 72: 1048-1063.

2. Spray TL, Roberts WC. Tension on coronary bypass conduits. J Thorac Cardiovasc Surg 1976; 72: 282-287.

3. Eguaras MG, Garcia MA, Granados J, Concha M. Accurate length adjustment of right or circumflex coronary artery bypass grafts. J Cardiovasc Surg 1986; 27: 681-682.

4. Durrani A, Sim W, Grignani RT. Accurate length adjustment of aortocoronary saphenous vein bypass grafts. Ann Thorac Surg 1998; 66: 966-967. 